FACTA UNIVERSITATIS

Series: Physical Education and Sport, Vol. 17, No 2, 2019, pp. 419 - 426

https://doi.org/10.22190/FUPES190714037R

Professional article

\title{
WHAT ADVICE SHOULD BE GIVEN TO PEOPLE WITH EPILEPSY - PHYSICAL ACTIVITY, YES OR NO?
}

\author{
UDC 796.01:616.853
}

\author{
Željka Rogačํㅜ, Rosa Čukić Ćorović ${ }^{2}$, \\ Branko Lutovac ${ }^{1}$, Dimitrije Nikolic ${ }^{3,4}$ \\ ${ }^{1}$ Institute for Children's Diseases-Clinical Centre of Montenegro, Podgorica, Montenegro \\ ${ }^{2}$ Faculty of Pharmacy, University of Montenegro, Podgorica, Montenegro \\ ${ }^{3}$ University Children's Hospital, Belgrade, Serbia \\ ${ }^{4}$ Faculty of Medicine, University of Belgrade, Belgrade, Serbia
}

\begin{abstract}
People with epilepsy (PWE) face numerous difficulties. Because of the complicity of the disease, a thorough treatment of those patients requires a multidisciplinary approach. One of the important aspects such an approach should take into account is the quality of life of PWE. Apart from the pharmacological solutions, it is necessary to further search for nonpharmacological ones. In addition to raising education and the level of awareness this means dealing with physical activity due to numerous benefits. Sometimes doctors themselves do not know how to assess the risks and benefits, and in order to protect the patients, advise that it is best not to engage in any sport, thereby contributing to the vicious circle - fear - stigma poor quality of life. The aim of this paper is to unify the experiences of various researchers on this topic, to point out the many difficulties that PWE meet, and to define guidelines in the workplace. We will try to answer a commonly posed question which sometimes in practice remains unclarified, that is - whether epilepsy patients should be involved in sports, if so which sport, and what intensity of physical activity would be allowed, and whether they can participate in competitions. In order to provide patients with a decent life quality it is necessary to work on the education of patients and doctors, and the society as well. While giving recommendations, it is necessary to follow the guidelines, among which the most comprehensive ones were created by the International League Against Epilepsy (ILAE) in 2016.
\end{abstract}

Key words: Epilepsy, Physical Activity, Quality of Life

Received July 14, 2019/ Accepted November 11, 2019

Corresponding author: Željka Rogač

Institute for Children's Diseases-Clinical Centre of Montenegro, bb Ljubljanska, Podgorica, Montenegro

Phone: +382 20412412 •E-mail: zeljka.rogac89@gmail.com 


\section{INTRODUCTION}

Epilepsy is a neurological disease affecting around 65 million people in the world, characterized by either at least 2 unprovoked seizures within $24 \mathrm{~h}$, or by one unprovoked seizure with a risk of over $60 \%$ of a second occurrence, or by the occurrence of epileptic syndromes (Hafele, Freitas, \& Rombaldi, 2017). According to Hafele at al. (2017), together with headaches, epilepsy is one of the most common chronic neurological diseases. As it is the case with most chronic diseases, patients face numerous difficulties (Fisher et al., 2014). A proper approach to people with epilepsy (PWE) does not consist only of determining the therapy to control the seizure, but implies a multidisciplinary approach (Cramer, Blum, Reed \& Fanning, 2003). The impact of epilepsy on the quality of life has a multidimensional character with a series of very complex functional and physical-psychosocial domains and subdomains (Fernandes, Snape, Beran, \& Jacoby, 2013). Besides potentially limiting influence of seizures in the spheres of the physical and cognitive, problems also appear in sociological, emotional, school functioning, leisure activities, etc. (Stefanović, 2016). Neurological clinics often fail to refer to the quality of life of PWE (Schachter, 2008). In other words, in many situations clinics do not take into account what actual constraints patients are facing, and what are, on the other hand, imposed constraints - be it the lack of education among patients, or the stigmatization coming from their environment, or finally the lack of doctors' knowledge (Yuen, Keezer, \& Sander, 2018).

Therefore, a question that is often posed is whether epilepsy patients should participate in sports, and if so - which sport, what intensity their physical activity is allowed to be, and whether they are allowed to participate in competitions (De Lima et al., 2013). Sometimes doctors themselves face difficulties when trying to assess such risks and benefits. In order to protect their patients, doctors advise them that it is best not to engage in any sport, thereby contributing to a vicious circle - fear - stigma - poor quality of life (Fernandes et al., 2013).

Many people with epilepsy in the world and the region have dealt with this issue, and we have tried to address this topic from different points of view, and combine experiences and recommendations that can make it easier to work in the everyday practice of general practitioners, neurological clinics and sports medicine clinics.

The aim of this paper is to unify the experiences of various researchers on this topic, to point out the many difficulties that PWE meet, and to define guidelines in the workplace.

\section{QUALITY OF LIFE OF PEOPLE WITH EPILEPSY - AN OVERVIEW OF RELEVANT STUDIES}

With the advancement of medicine, in the treatment of chronic diseases, one should not focus only on the reduction of symptoms, but also on the quality of life of those afflicted (Kostić, 2017). Bearing that in mind, there have been numerous studies around the world that have examined the quality of life of PWE. In most of them, the next step after taking the socio-demographic data of the diseased, and the control group - healthy populations, was a comparison of the parameters of psycho-physical functioning (Hafele et al., 2017). For example, a study by London students has shown that a significant number of psychiatric conditions and somatisation are more prevalent among PWEs. Similarly, other chronic diseases, such as heart disease, hypertension, chronic obstructive pulmonary disease, neoplasms, are also more common among PWEs (Yuen et al., 2018). A cross sectional study from Canada showed that people with epilepsy 2.5 times more often have ulcerations in the digestive tract, and 2 to 3 times more often have Crohn's disease, and a relevant UK study has shown that they have dementia 5 to 25 times more often 
(Keezer, Sisodiya, \& Sander, 2016). When compared with the usual population, people with epilepsy face a greater degree of depression, anxiety, which leads to a decline in quality of life (Stevanović, 2006). Furthermore, the medicines that are used can lead to obesity, bone loss, gastrointestinal complaints, appetite suppression, and so on (Hirtz et al., 2007). According to the 2005 Public Health Survey in California, people with epilepsy have a lower level of education, lower annual income, lower health status (Dimberg \& Burns, 2005). Many people with epilepsy (as much as 30\%) have a problem with cognitive functioning - including learning, memory, attention disorder, reduced ability to execute orders (Gordon, Dooley, \& Brna, 2010). Such deficiency in cognitive abilities comes as a result of numerous factors, such as the etiological causes of epilepsy, repeated seizures, undesirable effects of drugs (Stevanović, 2006). Modern epileptology is focused on searching for non-pharmacological solutions that would lead to the improvement of the quality of life of PWEs (Hafele et al., 2017). Among those solutions, the most common ones refer to raising the level of education of both the diseased and the environment with an aim to reduce stigmatization, as well as the physical activity, which itself leads to a number of benefits (Pimentel, Tojal, \& Morgado, 2015)

\section{EPILEPSY AND PHYSICAL ACTIVITY}

By the 1980s, it was unclear and unresolved whether PWEs should be allowed to engage in physical activity. This is a question also debated in the case of athletes with epilepsy who are in a dilemma whether they should stop exercising (Gotze, Kubicki, Munter, \& Teichmann, 1967). As a result, a large number of patients, once encountered with a diagnosis, stop practicing sports (Zack, \& Kobau, 2015). Today, when it has been proven in many studies that physical activity is desirable, further examinations of athletes in the epidemiological team (PWE) have shown that they are afraid of the possibility of accidentally injuring a teammate and causing a seizure (Gordon et al., 2010). This means that those who have epilepsy still feel unequal and therefore often stop practicing sports permanently (Pimentel et al., 2015). A reason why doctors themselves are sometimes in a dilemma when giving advice is the unresolved question of whether a physical activity can provoke a seizure. This is, therefore, an important issue to address, an issue where guidelines have to be followed and work on patient education has to be advanced in neurological, sports medicine clinics, as well as in the Public Health Promotion Institutes (Arida et al., 2010).

Exercising leads to neurotransmitter activation, raises the and level of 5 - HT, NA (Khanzada, Soomro, \& Khan, 2015). Many studies show that depression and anxiety that often occur in PWE is followed by a low level of these neurotransmitters (Arida, Cahalhveiro, \& Scorza, 2012). Therefore, it is reasonable to draw a conclusion that physical activity brings benefits (Kostić, 2017). Physical activity reduces cardiovascular, pulmonary diseases, contributes to the desired physical weight, conservation of bone mass which can be impaired due to the use of antiepileptic drugs (Arida, DeArmeida, Cavalheiro, \& Scorza, 2013). One of the possible strategies for improving cognition is physical activity and exercise (Bačanc, Milićević, Kasum, \& Marinković, 2014).

\section{IF THIS IS THE CASE, IS THERE ANY ROOM FOR WORRY?}

A study examining the relationship between the IPAQ score of epilepsy (International Physical Activity Questionnaire) and the score of quality of life of PWE (QUILE-31) and 
the Stigma Scale of Epilepsy score (SSE) among PWEs has showed that a third of PWEs were irregularly physically active and that their QUILE was lower and SSE was higher (Tedrus, Sterca, \& Pereira, 2017). 23\% of PWE had previously trained, but stopped training due to a fear of seizure. Lower physical activity was associated with depression, poor quality of life and a higher perception of the stigma (Tedrus et al., 2017). Another study has focused on the effects of physical activity of PWEs (Wong \& Wirrel, 2006). The result is that exercise can reduce the number of seizures, as well as reduce anxiety and depression, and as such may be a candidate for the nonpharmacological treatment of epilepsy (Thapar, Kerr, \& Harold, 2009).

However, a study in Scandinavia has shown that $40 \%$ of PWEs have reported a lower number of seizures after engaging in hard physical activity, but $10 \%$ of seizures reported a seizure following intense physical activity (Ablah et al., 2009). This should certainly be taken into account when giving advice in an ambulance.

It is understandable that seizures can nevertheless be harmful during physical activities, and PWEs have to be more cautious when choosing sports. In other words, PWEs must choose between pros and cons. It is true that excessive physical activity can lead to changes in electrolyte balance, hypoglycaemia, hyperthermia, hypoxia, fatigue and stress, which can be provocative for seizures (Gates \& Spiegel, 1993). For ethical reasons, there are no studies exposing humans to enormous physical exhaustion. In a study on animals, which led to the peak of physical exhaustion, none of them had a seizure during nor immediately after exercising (Arida et al., 2013). Numerous studies that have followed EEG activity after dealing with moderate physical activity at a certain time interval have been conducted. A significant number of patients show no deterioration of interacting EEG records during hyperventilation, and this could not be used as a criterion for the patients' tendency toward seizures during physical activity (Arida, R.M., Scorza, F.A., Terra, V.C., Scorza, C.A., DeAlmeida, A.C., \& Cavalheiro, E.A. (2009). Increased ventilation during physical activity is a compensatory homeostatic mechanism and does not lead to respiratory alkalosis, as in EEG labs during examination (Arida et al., 2009). Seizures during exercise can be associated with acute metabolic or respiratory changes (Nakken, 1999). The respiratory control system in non-preserving individuals achieves a homeostatic balance and loses it faster (Nakken, 1999). According to the results of Nakken's study (1999), about $2 \%$ of patients have training-induced seizures (they have a crisis in at least half of the exercises), most (63-84\%) have no seizures during or after physical activities. Consequently, complex focal seizures are more often activated by exercise because the lumbar lobe and limbic system are more sensitive to exercise caused by epileptiform discharges than other parts of the brain (Arida et al., 2010).

\section{AND FINALLY, WHAT ARE THE RECOMMENDATIONS?}

First and foremost, there is no universal approach to this group of patients, and rather individual approaches should be developed. It is also important to bear in mind the age of the patient, type of epilepsy, frequency of seizure, responsibility, ability to monitor if a child is concerned, the likelihood of seizures, and the choice of sports. It is also necessary to adhere to the existing recommendations, which have changed over the past few decades. In 1997, the ILAE recommended that all sports be allowed except for flying and diving (Manuel \& Feinstein, 2018). 
Recommendations have, however, changed. In 2016, the ILAE issued new guidelines for dealing with physical activity that are somewhat more liberal. The novelty is that in the selection of sports discipline, the nature and characteristics of the epileptic seizure and the use of AEL are taken into account (Capovilla, Kaufman, Perucca, Moshé, \& Arida, 2016).

According to the ILAE guidelines, sports disciplines are divided into three groups according to the risk of injury or death to persons with epilepsy, observers or teammates (Table 1). Sports disciplines belonging to Group 1 are those with no significant risk associated. This means that even if a seizure occurs, there would be no additional risk for a person, teammates, observers. Sports disciplines in Group 2 are those that bring a moderate risk. In other words, there is a possible risk for the patients but there is no risk for the teammates or observers. Finally, Group 3 consists of sports disciplines with a high risk. Those disciplines are associated with high risk of injury or death for people with epilepsy, and in some of these sports disciplines, there is a danger for the observers/teammates (Capovilla et al., 2016).

Table 1 Categorization of sports by level of risk of injury or death for PWEs, or for bystanders, should a seizure occur during the event (Capovilla et al., 2016)

\begin{tabular}{lll}
\hline Group 1 & Group 2 & Group 3 \\
\hline Athletics & Alpine skiing & Aviation \\
Baseball & Archery & Climbing \\
Basketball & Athletics (jump jump) & Cross-country skiing \\
Bowling & Biathlon & Diving \\
Cross-country skiing & Boat riding & Motorcycling \\
Dancing & Boxing & Parachute jumping \\
Football & Cycling & Rodeo \\
Handball & Fencing & Surfing \\
Hockey on the grass & Gymnastics & Windsurfing \\
Ice skating & Horseback riding & \\
Judo & Ice hockey & \\
Rugby & Karate & \\
Squash & Rowing of canoes & \\
Tennis & Skateboarding & \\
Table tennis & Skating & \\
Wrestling & Swimming & \\
& Triathlon & \\
& Water skiing & \\
\hline
\end{tabular}

After determining which group a sport discipline that a PWE wants to participate in belongs to, all the characteristics of epilepsy are taken into account in order to evaluate whether participation in the desired sports discipline is recommended or whether participation in other, less risky ones is recommended (Capovilla et al., 2016). If the risk of a repeat of an epileptic seizure is symptomatically low and there are no additional contraindications, these individuals should be encouraged to engage in physical activity from Group 1 sports disciplines, and, upon a recommendation from a neurologist, they can also participate in sports disciplines from Group 2 and 3, only after a detailed clinical examination, an informed consent of the person with epilepsy or the consent of the parents of a diseased child (Table 2). 
Table 2 Suggestions for physical activities/sports participation for PWEs or individuals with other seizure disorders (Capovilla et al., 2016)

\begin{tabular}{|c|c|c|}
\hline \multicolumn{3}{|c|}{ One or more symptomatic seizures } \\
\hline Group 1 & Group 2 & Group 3 \\
\hline \multicolumn{3}{|c|}{ permitted to practice and compete in all sports disciplines } \\
\hline \multicolumn{3}{|c|}{ Single unprovoked seizure } \\
\hline $\begin{array}{l}\text { Group 1 } \\
\text { permitted to practice and } \\
\text { compete in sports disciplines } \\
\text { after an appropriate } \\
\text { medical/neurologic assessment }\end{array}$ & $\begin{array}{l}\text { Group } 2 \\
\text { permitted to practice and } \\
\text { compete in sports disciplines } \\
\text { after } 12 \text { months of being seizure- } \\
\text { free, and an appropriate } \\
\text { medical/neurologic assessment }\end{array}$ & $\begin{array}{l}\text { Group } 3 \\
\text { permitted to practice and } \\
\text { compete in sports disciplines } \\
\text { after } 12 \text { months of being seizure- } \\
\text { free, and an appropriate } \\
\text { medical/neurologic assessment, } \\
\text { with appropriate supervision } \\
\text { during the activity }\end{array}$ \\
\hline \multicolumn{3}{|c|}{ Seizure-free (12 months or longer) } \\
\hline Group 1 & Group 2 & Group 3 \\
\hline \multicolumn{3}{|c|}{ permitted to practice and compete in all sports disciplines } \\
\hline \multicolumn{3}{|c|}{ Sleep-related seizures only } \\
\hline $\begin{array}{l}\quad \text { Group } 1 \\
\text { permitted to practice and } \\
\text { compete in sports disciplines } \\
\text { after an appropriate } \\
\text { medical/neurologic assessment }\end{array}$ & $\begin{array}{l}\text { Group } 2 \\
\text { permitted to practice and } \\
\text { compete in sports disciplines } \\
\text { after } 12 \text { months of monitoring } \\
\text { and an appropriate } \\
\text { medical/neurologic assessment }\end{array}$ & $\begin{array}{l}\text { Group } 3 \\
\text { not permitted to practice and } \\
\text { compete in sports, but may be } \\
\text { considered, at the neurologist's } \\
\text { discretion after } 12 \text { months of } \\
\text { follow-ups, with appropriate } \\
\text { supervision during the activity }\end{array}$ \\
\hline \multicolumn{3}{|c|}{ Seizures without impaired awareness } \\
\hline \begin{tabular}{l}
\multicolumn{1}{c}{ Group 1} \\
permitted to practice and \\
compete in sports disciplines \\
after an appropriate \\
medical/neurologic assessment
\end{tabular} & $\begin{array}{l}\text { Group } 2 \\
\text { permitted to practice and } \\
\text { compete in sports disciplines } \\
\text { after } 12 \text { months of monitoring } \\
\text { and an appropriate } \\
\text { medical/neurologic assessment, } \\
\text { with appropriate supervision } \\
\text { during the activity }\end{array}$ & $\begin{array}{l}\text { Group } 3 \\
\text { not permitted to practice and } \\
\text { compete in sports, may be } \\
\text { considered, at the neurologist's } \\
\text { discretion after } 12 \text { months of } \\
\text { follow-ups, with appropriate } \\
\text { supervision during the activity }\end{array}$ \\
\hline \multicolumn{3}{|c|}{ Seizures with impaired awareness } \\
\hline $\begin{array}{l}\quad \text { Group } 1 \\
\text { permitted to practice and } \\
\text { compete in sports disciplines } \\
\text { after an appropriate } \\
\text { medical/neurologic assessment }\end{array}$ & $\begin{array}{l}\text { Group } 2 \\
\text { permitted to practice and } \\
\text { compete in sports disciplines, } \\
\text { after an appropriate } \\
\text { medical/neurologic assessment, } \\
\text { with appropriate supervision } \\
\text { during the activity }\end{array}$ & $\begin{array}{l}\text { Group } 3 \\
\text { not permitted to practice and } \\
\text { compete in sports, but may be } \\
\text { considered at the neurologist's } \\
\text { discretion after } 12 \text { months of } \\
\text { follow-ups, with appropriate } \\
\text { supervision during the activity }\end{array}$ \\
\hline \multicolumn{3}{|c|}{ Medication withdrawal } \\
\hline $\begin{array}{l}\text { Group } 1 \\
\text { permitted to practice and } \\
\text { compete in sports disciplines } \\
\text { after an appropriate } \\
\text { medical/neurologic assessment, } \\
\text { with appropriate supervision } \\
\text { during the activity }\end{array}$ & $\begin{array}{l}\text { Group } 2 \\
\text { permitted to practice and } \\
\text { compete in sports disciplines, } 6 \\
\text { months after the cessation of } \\
\text { treatment, with appropriate } \\
\text { supervision during the activity }\end{array}$ & $\begin{array}{l}\text { Group } 3 \\
\text { permitted to practice and } \\
\text { compete in sports disciplines, } 6 \\
\text { months after the cessation of } \\
\text { treatment, with appropriate } \\
\text { supervision during the activity }\end{array}$ \\
\hline \multicolumn{3}{|c|}{ Epilepsy resolved (no seizures $>10$ years and off AED > 5 years) } \\
\hline Group 1 & $\begin{array}{c}\text { Group } 2 \\
\text { practice and compete in all spor }\end{array}$ & Group 3 \\
\hline
\end{tabular}


A certain flexibility in decision-making is possible, and neurologist's discretion in unclear situations should be taken into account, among other considerations (Fisher et al., 2014).

\section{CONCLUSION}

Epilepsy, as well as other chronic diseases, requires a multidisciplinary approach. The patients face stigma, fear, anxiety, undesirable effects of therapy, and are more susceptible to other comorbidities. In addition to pharmacological solutions, it is necessary to look for those non-pharmacological ones. Among such solutions, there is not only raising education and the level of awareness, but also a need to exercise, due its numerous benefits. While recommendations are given, it is necessary to follow the guidelines, among which most comprehensive are the ILEA ones from 2016.

\section{REFERENCES}

Ablah, E., Haug, A., Konda, K.,Tinius, A.M., Ram, S., Sadler, T., et al., (2009). Exercise and epilepsy: a survey of Midwest epilepsy patients. Epilepsy \& Behavior, 14, 162-166.

Arida, R.M., DeArmeida, A.C., Cavalheiro, E.A., \& Scorza, F.A. (2013). Experimental and clinical findings from physical exercise as complementary therapy for epilepsy. Epilepsy \& Behavior, 26, 273-278.

Arida, R.M., Cahalhveiro, E.S., \& Scorza, F.A. (2012). From depressive symptoms to depression in people with epilepsy: Contribution of physical exercise to improve this picture. Epilepsy \& Research, 99, 1-13.

Arida, R.M., Scoorza, F.A., \& Gomes da Silva, S. (2010). The potential role of physical exercise in the treatment of epilepsy. Epilepsy and Behavior, 17(4), 432-435.

Arida, R.M., Scorza, F.A., Terra, V.C., Scorza, C.A., DeAlmeida, A.C., \& Cavalheiro, E.A. (2009). Physical exercise in epilepsy: what kind of stressor is it? Epilepsy \& Behavior, 16, 381-387.

Bačanac, Lj., Milićević, M.M., Kasum, G, \& Marinković, M. (2014). Competitive anxiety, self-confidence and psychological skills in top athletes with and without disabilities: a pilot study. Facta Universitatis Series Physical Education and Sport, 12(2), 59-70.

Capovilla, G., Kaufman, K.R., Perucca, E., Moshé, S.L., \& Arida, R. M. (2016). Epilepsy, seizures, physical exercise, and sports: a report from the ILAE Task Force on Sports and Epilepsy. Epilepsia, 57, 6-12.

Cramer, J.A., Blum, D., Reed, M., \& Fanning, K. (2003). The influence of comorbid depression on quality of life for people with epilepsy. Epilepsy \& Behaviour, 4, 515-521.

De Lima, C., De Lira, C.A.B., Arida, R.M., Andersen, L.M., Matos, G., Guilhoto, L.M.F.F., et al., (2013). Assotiation between leisure time, physical activity, and mood disorder levels in individuals with epilepsy. Epilepsy \& Behavior, 28, 47-51.

Dimberg, E. L., \& Burns, T. M. (2005). Management of common neurologic conditions in sports. Clinics in Sports Medicine, 24(3), 637-662.

Fernandes, P.T., Snape, D.A., Beran, R.G., \& Jacoby, A. (2013). Epilepsy stigma: what do we know and where next? Epilepsy \& Behavior, 28, 163-167.

Fisher, R.S., Acevedo, C., Arzimanoglo, A., Bogacz, A., Cross, J.H., Elger, C.E., et al., (2014). ILAE official report: a practical clinical definition of epilepsy. Epilepsia, 55, 475-482.

Gates, J.R., \& Spiegel, R.H. (1993). Epilepsy, sport and exercise. Sports Medicine, 15, 1-5.

Gotze, W., Kubicki, S.T., Munter M., \& Teichmann. J. (1967). Effect of physical exercise on seizure threshold. Diseases of the Nervous System, 28(10), 664-667.

Gordon, K.E., Dooley, J.M., \& Brna, P.M., (2010). Epilepsy and activity-a population based study. Epilepsia, 51, 2254-2259.

Hafele, C.A., Freitas, M.P., \& Rombaldi, A.J. (2017). Are physical activity levels associated with better health outcomes in people with epilepsy? Epilepsy \& Behavior, 72, 28-34.

Hirtz, D., Thurman D.J, Gwinn, H.K, Mohamed, M, Chaidhuri, A.R, \& Zalutsky, R. (2007). How common are the "common" neurologic disorders? Neurology, 68, 326-327.

Keezer, M.R, Sisodiya S.M, \& Sander, J.W. (2016). Comorbidities of epilepsy: Current concepts and future perspectives. The Lancet Neurology, 15(1), 106-115. 
Khanzada, F.J., Soomro, N., \& Khan, S.Z. (2015). Association of physical exercise on anxiety and depression among adults. Journal of the College of Physicians and Surgeons Pakistan, 25(7), 546-548.

Kostić, M. (2017). Stress, adaptation and the possible effect of physical exercise. Facta Universitatis Series Physical Education and Sport, 15(2), 329-340.

Manuel, C., \& Feinstein, R. (2018). Sports participation for young athletes with medical conditions: Seizure disorder, infections and single organs. Current Problems in Pediatric and Adolescent Health Care, 48(56), 161-171.

Nakken, K.O. (1999). Physical exercise in outpatients with epilepsy. Epilepsia. 40, 643-651.

Pimentel, J., Tojal, R., \& Morgado, J. (2015). Epilepsy and physical exercise. Seizure, 25, 87-94.

Schachter, S.C. (2008). Complementary and alternative medical therapies. Current Opinion in Neurology, 21(2), 184-189.

Stevanović, D. (2006). Opšte karakteristike kvaliteta života povezanog sa zdravljem kod dece i adolescenata sa epilepsijom (General characteristics of health - related quality of life among children and adolescent with epilepsy). Aktuelnosti iz neurologije, psihijatrije i graničnih područja, 14(3-4), 30-44. In Serbian

Tedrus, G.M.A.S., Sterca, G.S., \& Pereira, P.B. (2017). Physical activity, stigma, and quality of life in patients with epilepsy. Epilepsy \& Behavior, 77, 96-98.

Thapar, A., Kerr, M., \& Harold, G., (2009). Stress, anxiety, depression, and epilepsy: Investigating the relationship between psychological factors and seizures. Epilepsy \& Behavior, 14, 134-140.

Wong, J., \& Wirrell, E. (2006). Physical activity in children/teens with epilepsy compared with that in their siblings without epilepsy. Epilepsia, 47(3), 631-639.

Yuen, A.W.C., Keezer, M.R., \& Sander, J.W. (2018). Epilepsy is a neurological and systemic disorder. Epilepsy \& Behavior, 78, 51-76.

Zack, M.M., \& Kobau.R. (2015). National and state estimates of the numbers of adults and children with active epilepsy - United States, 2015. MMWR Morbidity and Mortality Weekly Report, 66(31), 821-825.

\section{KOJI SAVET TREBA DATI LJUDIMA SA EPILEPSIJOM - FIZIČKA AKTIVNOST, DA ILI NE?}

Oboleli od epilepsije se često susreću sa brojnim poteškoćama tokom svakodnevnog života, pa stoga njihovo praćenje i lečenje zahteva multidisciplinarni pristup. Jedan od važnih činilaca koji mora da se ima $u$ vidu je i kvalitet života obolelih. Osim unapređenja terapije antiepilepticima, moderna epileptologija akcenat stavlja i na nefarmakološke pristupe, a jedan od njih je i bavljenje fizičkom aktivnošću, za koju je poznato da sa sobom nosi brojne benefiti po zdravlje pojedinca. Međutim, lekari su često u nedoumici kada treba da odluče o potencijalnom riziku od bavljenja sportom obolelih od epilepsije, nesvesno na taj način doprinoseći začarnom krugu ,strah-stigmaloš kvalitet života'.' Stoga, cilj ovog rada je da se nakon osvrta na relavantna istraživanja na ovu temu, definišu smernice koje bi olakšale savetovanje pacijenata obolelih od epilepsije vezano za bavljenjem sportom. Pokušaćemo da odogovorimo na često postavljena pitanja koja u svakodnevnoj praksi nekada ostaju nerešena - da li se ljudi sa epilepsijom smeju baviti sportom, ukoliko da - u kojoj meri, i da li je dozvoljeno učestvovanje na sportskim takmičenjima. U cilju poboljšanja kvaliteta života obolelih od epilepsije neophodna je edukacija $i$ međusobna saradnja pacijenata, lekara $i$ društva. Pilikom davanja saveta vezano za bavljenje sportom, potrebno je pratiti najnovije smernice Internacionalne lige za borbu protiv epilepsije, objavljene 2016. godine.

Ključne reči: epilepsija, fizička aktivnost, kvalitet života 